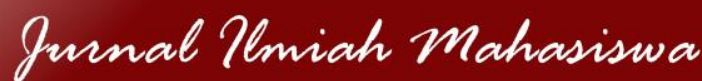

\section{TOTALITAS CINTA DALAM SYAIR RABI'AH AL-ADAWIYAH: TINJAUAN SEMIOTIKA PIERCE}

\author{
Fitriani
}

UIN Sunan Kalijaga Yogyakarta

fitrianiofficialemail@gmail.com

\author{
Diterima: 5 Juli 2021 \\ Direvisi: Juli-25 September 2021 \\ Diterbitkan: 28 September 2021
}

\begin{abstract}
Rabi'ah al-Adawiyah is famous Sufi who is known for several poems which are full of the meaning and and complexity of loving God. The complexity requires study that is able to pry the depth of Rabi'ah alAdawiyah's loving God and how she symbolizes her love. This study aims to review the totality of love based on the semiotic perspective of Charles Sanders Peirce, namely icon, index, and symbol. The research uses descriptive-qualitative method that uses poetry as data and data source, considers as data collection method, and uses analytical techniques with three stages, namely data provision, data analysis, and analysis results. The results of the study show that the depth of Rabi'ah al-Adawiyah's love is illustrated by two icons; stars and palaces, eight indexes; sacrifice, willingness, attachment, fear of wrongdoing, indifference to rewards, and unwillingness to turn to others, as well as of the three symbols; cup and wine, night and day, and I am worship.
\end{abstract}

Keywords: Poetry, Semiotics, Totally of Love

\section{ABSTRAK}

Rabi'ah al-Adawiyah adalah seorang tokoh sufi terkemuka yang dikenal dengan beberapa syairnya yang penuh akan makna dan kompeksitasnya akan cinta ilabiah. Kompleksitas tersebut membutubkan kajian yang mampu membongkar lebih jaub terkait sejauh mana cinta ilabiah Rabi'ah al-Adawiyah dan bagaimana ia menyimbolkan kecintaannya tersebut. Penelitian ini bertujuan untuk. mengulas bentuk totalitas cinta dalam sya'ir Rabia'ah Al Adawiyah berdasarkan perspektif semiotika Charles Sanders Peirce, yaitu ikon, indeks, dan simbol. Proses penelitian ini dijalankan dengan metode deskriptifkualitatif yang menjadikan syair Rabi'ah sebagai data dan sumber data, simak sebagai metode pengumpulan data, serta menggunakan teknis analisis dengan tiga tahap, yakni penyediaan data, analisis data, dan penyajian hasil analisis. Adapun basil penelitian menunjuk.kan bahwa kedalaman cinta Rabi'ah al-Adawiyah tergambarkan dari dua ikon; bintang dan istana, delapan indeks; pengorbanan, kerelaan, rasa kemelekatan, ketakutan untuk berbuat salah, ketidakpedulian terhadap imbalan, dan ketidakinginan untuk beralih kepada yang lain, serta dari tiga simbol; cawan dan anggur, malam dan siang, dan aku menghamba.

Kata Kunci: Syair, Semiotika, Totalitas Cinta 


\section{PENDAHULUAN}

Sastra di dunia Arab adalah bukti kelihaian para penulis Arab dalam mengolah diksi. Sejarah kesusastraan Arab mengabadikan bukti kongkret mengenai kemampuan mereka yang sudah terbangun jauh sebelum lahirnya sastrawan Barat muncul ke permukaan, yaitu terdapat beberapa karya yang terpilih menjadi kelompok mu'allaqat (karya yang digantungkan di dinding ka'bah).

Meskipun kegemilangan dunia sastra Arab disebut-sebut ada pada masa pra Islam (jahiliyah), namun tidak sedikit penulis junior yang masih eksis dengan karya-karyanya hingga sekarang. Mereka yang disebut sebagai penulis Arab mampu menyalurkan ide ke dalam berbagai aspek, bukan hanya aspek dalam dirinya secara internal, tetapi juga mampu mengeksplorasinya lebih jauh, seperti menyoal isu agama, sosial, politik, maupun budaya, sehingga tidak heran jika muncul persepsi dalam sejarah bahwa tingkat intelektualitas orang Arab dahulu diukur dari kemampuannya bersastra, khususnya dalam menulis dan menggubah syair. Fachruddin menyebutkan dalam buku Pengantar Sejarah dan Madzhab Linguistik Arab, untuk mengukur seberapa tingkat intelektualitas seseorang pada zaman itu, kepandaian membuat syair adalah salah satu parameter utama (2017:37)

Selain bersyair, kemampuan lain yang juga diperhitungkan dalam sejarah kesustraan Arab adalah seni berbahasa dalam wujud prosa yang dijadikan sebagai daya tarik lakilaki dalam merayu wanita (Fachruddin, 2017:38). Seni berbahasa berupa rayuan tersebut merupakan bentuk ekspresi cinta, di mana tingkat kedalamannya bisa dipengaruhi oleh kedalaman cinta yang dirasakan oleh penulisnya. Semakin dalam cinta yang dirasakan, semakin besar pula kemungkinan suatu karya lahir dengan substansi yang mendalam, sehingga sering kali dalam suatu karya ditemukan ungkapan cinta yang disimbolkan dengan sesuatu yang lain, agar pesan yang disampaikan terkesan lebih indah dan tidak biasa-biasa saja. Relevansi cinta dan kualitas produk sastra tidak bisa dipungkiri terjadi, entah cinta yang memengaruhi penulisnya atau pun karya yang membawa pengaruh kepada pembacanya. Olehnya, cinta adalah termasuk tema sentral yang tidak pernah lekang oleh waktu.

Simbolisasi cinta secara umum bisa dilihat dari Adam dan Hawa, mulai pada awal penciptaan Adam, hingga kehadiran Siti Hawa yang kemudian menjadi pasangan hidupnya, kemudian menunjukkan bahwa pada dasarnya cinta adalah bagian yang tidak terlepaskan dari kehidupan manusia, baik itu untuk dirinya dengan lingkungan, maupun cinta kepada penciptanya. Cinta lahir melalui keterkaitan diri dengan yang lain, tumbuh di atas proses interaksi, dan frekuensinya bisa sampai pada level abadi berdasarkan situasi dan kondisi yang mempengaruhinya.

Itulah gambaran mendasar mengenai cinta yang akhirnya banyak berimplikasi kepada tema kepenulisan sastra. Salah satu penulis di dunia Arab yang dekat dengan tema tersebut dan yang banyak dibahas dalam berbagai studi keilmuan adalah Rabi'ah alAdawiyah. Ia adalah seorang tokoh sufi terkemuka yang dikenal dengan beberapa syair yang ia tulis dengan penuh penghayatan dan sarat akan makna cinta ilahiah. Melalui

Jurnal Ilmiah Mahasiswa Raushan Fikr Vol. 10, No. 2 Juli-Desember 2021 
syair-syairnya, ia berhasil membuktikan bahwa cinta tidak hanya ada pada ruang horisontal, tetapi juga vartikal. Pada umumnya lingkup cinta terlalu dipersempit pada ranah duniawi, padahal ada yang lebih esensial, lebih utama dari yang utama, bahkan tidak dapat ditandingi oleh apa pun, yaitu cinta kepada Maha Pencipta.

Berdasarkan penjelasan-penjelasan tersebut, maka cinta dengan kompleksitasnya menjadi menarik ketika dituangkan ke dalam karya sastra, sebagaimana syair Rabi'ah alAdawiyah yang menjangkau cinta vartikal secara total. Namun, kompleksitas dan totalitas tersebut membutuhkan kajian yang mampu membongkar lebih jauh terkait sejauh mana cinta ilahiah Rabi'ah al-Adawiyah dan bagaimana ia menyimbolkan kecintaannya tersebut.

Syair atau puisi sebagai salah satu karya sastra dapat dikaji dari bermacam aspek, baik intrinsik maupun ekstrinsik. Ia dikategorikan sebagai produk sastra yang cukup singkat dan padat, namun beribu makna. Kajian terhadap puisi tidak pernah terlupakan, bahkan hingga masa moderen saat ini yang sangat sarat akan lahirnya berbagai macam karya baru, puisi tetap saja eksis untuk ditulis dan dibaca. Meskipun begitu, puisi yang disebut sebagai karya indah tidak jarang membuat pembaca gagal paham terhadap pesan yang sebenarnya ingin disampaikan oleh penulis, apalagi dari kajian ketandaannya.

Hal tersebut menjadi landasan penulis untuk melakukan penelitian mengenai syair dari Rabi'ah Al-Adawiah dengan kajian semiotik, agar berbagai pesan mendalam yang tertuang dalam karya tersebut terbongkar secara sistematis. Semiotik sendiri dikenal sebagai ilmu yang mempelajari tentang tanda dalam sistem bahasa, begitu pun tulisan yang berbentuk puisi. Pada dasarnya karya sastra berupa puisi merupakan cerminan dari perasaan, pengalaman dalam hubungan penulis dengan kehidupan. Hal-hal yang muncul dari keterkaitan dengan kehidupan akan menjadi penting dan dibutuhkan oleh siapa saja yang berinteraksi dengannya, begitu lah yang terjadi dengan puisi, namun yang menjadi kendalanya adalah tidak semua pembaca mampu melakukan pembacaan secara holistik terhadap pesan yang dibangun di dalam puisi, sehingga dibutuhkan suatu pisau bedah yang mampu menemukan pesanpesan tersebut.

Terkait dengan kebutuhan analisis tersebut, maka semiotika menjadi pilihan tepat untuk dapat membaca tanda di balik suatu teks. Melalui proses pembacaan tanda kebahasaan, pembaca perlu hadir di dalam karya sastra, agar makna yang tidak tertuliskan lebih mudah untuk diidentifikasi. Tidak hanya pada ranah kuantitas yang mengukur seberapa banyak tanda yang berhasil diidentifikasi, tetapi ranah kualitas juga sangat penting untuk mengukur seberapa mampu pembaca menjangkau ruang-ruang kosong yang ada dalam suatu karya, khususnya syair.

Semiotika dalam aktivitas penelitian merupakan bentuk pendekatan yang tidak jarang digunakan oleh para peneliti. Penggunaan pisau beda tersebut yang sarat akan tanda digunakan untuk menggali nilai dan juga makna melalui tanda-tanda yang ada di dalam karya sastra. Hal tersebut lah yang menjadi lingkup semiotika yang menjadikan

Jurnal Ilmiah Mahasiswa Raushan Fikr Vol. 10, No. 2 Juli-Desember 2021 
sistem tanda sebagai mangsa paling utama dalam pengembaraan ilmiah, sehingga suatu teks dipandang sebagai sistem yang dibalut dengan tanda. Asumsi yang dilahirkan dari kajian semiotika adalah karya sastra disebut sebagai sistem tanda yang digunakan sebagai sarana komunikasi antara pembaca dengan penulis melalui interaksi estetis secara tidak langsung.

Penelitian ini mencoba untuk membangun kolaborasi antara kajian semiotika dengan kajian sastra, di mana semiotika menjadi pisau bedah, sementara sastra menjadi objek yang dibedah. Penulis ingin menjadi salah satu pembukti bahwa sastra (karya sastra) menyediakan ruang bagi pembaca untuk melakukan interpretasi dengan caranya masing-masing. Penulis yang sekaligus menjadi pembaca karya sastra melakukan proses pembacaan dengan berfokus kepada pencarian tanda, agar pesan di dalamnya dapat terungkap secara menyeluruh. Tanda yang ada di dalam karya sastra berpotensi melahirkan banyak interpretasi makna, tergantung cara pembaca memberi penilaian terhadap teks karya yang dikaji. Setiap pembaca sastra harus menyadari bahwa ia sedang berhadapan dengan teks yang berbeda dengan teks yang lain. Hal tersebut selaras dengan yang diungkapkan oleh Jafar Lantowa (2017) bahwa teks sastra merupakan keseluruhan tanda yang perlu dimaknai oleh pembaca.

Ambarini (n.d.) menjelaskan lebih jauh mengenai tanda, bahwa tanda adalah perwakilan makna yang kehadirannya melalui cara implisit dan terwakili, di mana di balik keterwakilan tersebut ada makna. Adapun konvensi tanda merupakan perwujudan dari hasil kesepakatan mengenai keberadaan tanda itu sendiri, kehadiran dan juga proses pemaknaannya. Pada umumnya, proses pemaknaan pada tanda atau proses semiosis dilakukan dengan berbagai tahapan atau cara. Tahapan tersebut tergantung pada teori mana yang digunakan. Pada penelitian ini, penulis berfokus pada perspektif semiotika yang dibangun oleh Charles Sanders Peirce.

Menurut Peirce sendiri, penyebutan tanda diwakili dengan istilah semiosis, di mana disebutkan bahwa alam semesta terdiri atas tanda-tanda sebagai pandangan, bukan struktur. Proses semiosis dilakukan dengan tiga tahap atau dikenal dengan triadic, hubungan keterkaitan antara representamen $(\mathrm{R})$, objek (O), dan Interpretant (I). Konsep dasar tersebut disebutkan oleh Hoed (dalam Ambarini, hlm. 80) dalam salah satu buku semiotika. Berdasarkan pembahasan yang lebih detail, perspektif semiotika Peirce yang akan digunakan dalam penelitian ini adalah pemetaan tanda berdasarkan objeknya, yaitu ikon, indeks, dan simbol. Pemilihan fokus tersebut dilatarbelakangi oleh keinginan penulis untuk menggali bagaimana keterwakilan totalitas cinta yang digambarkan oleh Rabi'ah Al-Adawiyah melalui puisipuisinya, apa saja yang menjadi tanda totalitas tersebut, baik tanda itu berupa ikon, indeks, maupun simbol.

Penelitian yang berjudul "Pembacaan Totalitas Cinta dalam Syair Rabi'ah AlAdawiyah (Tinjauan Semiotika Pierce)" adalah penelitian yang menjadikan totalitas cinta sebagai objek formal dan syair Rabi'ah Al-Adawiyah sebagai objek material dengan

Jurnal Ilmiah Mahasiswa Raushan Fikr Vol. 10, No. 2 Juli-Desember 2021 
menggunakan teori semiotika Charles Sanders Peirce. Sebelum dilakukannya penelitian ini, penulis melakukan penelusuran literatur melalui berbagai sumber untuk mengetahui, seberapa banyak literatur yang mengguanakn semiotika Peirce sebagai pisau bedah, agar dapat memudahkan jalannya penelitian. Selain itu, penulis juga mencari tau literatur mana saja yang menjadikan syair Rabi'ah AlAdawiyah sebagai objek, sehingga dapat ditentukan apakah ini adalah penelitian yang baru atau terdapat penelitian terdahulu yang fokusnya sama.

Hasil penelusuran menunjukkan bahwa tidak sedikit literatur yang mengguanakan perspektif semiotika Peirce dan ditemukan beberapa literatur yang mengkaji syair Rabi'ah Al-Adawiyah, namun dengan pendekatan yang berbeda dan tidak ditemukan kajian terhadap syair Rabi'ah AlAdawiyah dengan teori semiotika Peirce. Oleh karena itu, untuk menambah literatur kajian semiotika dan menggali representasi totalitas cinta, penulis memilih kajian ini yang belum pernah dikaji sebelumnya dengan menggunakan objek dan pendekatan yang serupa.

Beberapa penelitian yang dianggap relevan, baik ditinjau dari pendekatan maupun objek yang digunakan antara lain: Pertama, artikel yang berjudul "Mahabbah dalam Tasawuf Rabi'ah Al-Adawiyah" yang ditulis oleh Wasalmi, mahasiswa Program Sarjana Konsentrasi Tafsir dan Hadits PPs UIN Alauddin Makassar Penelitian yang diterbitkan oleh penerbit Jurnal Sulesana pada tahun 2014, volume 9 Nomor 2 bertujuan untuk menganalisis konsep tasawuf dari
Rabi'ah Al-Adawiyah melalui syair-syairnya. Adapun salah satu hasil penelitian tersebut mengemukakan bahwa Cinta Ilahi (al-Hubb al-Ilaah) dalam pandangan kaum sufi seperti Rabi'ah Al-Adawiyah memiliki nilai tertinggi, bahkan kedudukan mahabbah dalam sebuah maqamat sufi terkait erat dengan maqam ma'rifat. Menurut kaum sufi, antara mahabbah dan ma'rifat bagaiman dua belah pisau yang tidak akan pernah terpisahkan (Wasalmi, 2014:85).

Demikian yang disebutkan dalam kesimpulannya, sehingga tergambarkan bahwa ada totalitas cinta dalam syair yang ditulis oleh Rabi'ah Al-Adawiyah. Penelitian tersebut cukup bagus, namun hanya dikaji dari aspek religiuitas, sehingga menurut penulis, masih dibutuhkan kajian semiotika untuk membongkar secara detail bagian mana saja dalam syair tersebut yang menandakan totalitas cinta dari Rabi'ah Al-Adawiyah.

Kedua, artikel yang berjudul "Analisis Semiotika Terhadap Puisi Rabi'atul Adawiyah Dan Kalimat Suci Mother Teresa", ditulis oleh Betty Mauli Rosa Bustam, mahasiswa Sekolah Pascasarjana UGM. Penelitian tersebut diterbitkan melalui jurnal "Analisa" Volume 21 Nomor 02 Desember 2014, halaman 227-238. Tujuan dilakukannya penelitian tersebut adalah untuk memunculkan pemaknaan yang berbeda dari makna yang telah diungkap oleh para peneliti terdahulu, yaitu menggunakan pisau analisis semiotika dengan berpusat pada pembacaan kembali puisi Rabi'ah dan kalimat suci Teresa. Adapun hasil penelitian tersebut lagi-lagi mengungkapkan sisi kedalaman cinta yang dimiliki oleh Rabi'ah Al-Adawiyah, bahwa

Jurnal Ilmiah Mahasiswa Raushan Fikr Vol. 10, No. 2 Juli-Desember 2021 
Rabi'ah menganggap segala yang ada di dunia ini tidak ada nilainya jika dibandingkan dengan "kehadiran" Tuhan di dalam dirinya. Menurutnya, Tuhan adalah satu-satunya tempat ia menumpahkan segala bentuk cinta yang ia miliki tanpa mengharapkan imbalan apapun (Bustam, 2014:237). Penelitian tersebut memang mampu mengungkap kedalaman cinta dari Rabi'ah Al-Adawiyah dengan menggunakan pendekatan, namun di dalamnya lebih mengulas terkait komparasi antara kedua objek, sehingga tidak berfokus kepada syair Rabi'ah Al-Adawiyah, apalagi teori yang digunakan lebih mengarah kepada pembacaan secara heuristik dan hermeneutik, sehingga memang fokusnya berbeda dengan yang akan diungkap dalam penelitian ini.

Ketiga, artikel yang berjudul "Representasi Cinta Pada Allah Dalam Syair Rabi'ah Al-Adawiyah Dan Syair Husain Manshur Al-Hallaj (Kajian Sastra Bandingan)" yang ditulis oleh Tati Nurhayati dari UIN Sunan Kalijaga Yogyakarta. Jurnal tersebut diterbitkan di Tafhim al-'Ilmi: Jurnal Pendidikan dan Pemikiran Islam pada Vol. 10 Nomor 2 (2019), tepatnya pada 01 Februari 2019. Tujuan penelitian tersebut dilakukan adalah untuk mengkaji dan memaparkan mengenai representasi cinta pada Allah dalam syair Rabi'ah al-Adawiyah dan syair al-Hallaj. Adapun hasilnya adalah ditemukan adanya keterkaitan dan persamaan dalam segi makna pokok kedua syair tersebut, serta ditemukan perbedaan pada beberapa bagian makna dan juga gaya penyajiannya (Nuryahati, 2019:11). Penelitian tersebut hampir sama dengan kajian pustaka yang disebutkan dalam poin pertama yang mengungkap penelitian dari aspek religiuitas, kemudian sama juga dengan poin kedua yang melakukan komparasi dua objek. Penelitian tersebut cukup bagus, namun ranah kajiannya lebih berfokus kepada aspek religiuitas dan tidak berfokus pada satu objek, sehingga menurut penulis, masih dibutuhkan kajian lebih lanjut yang lebih fokus dengan menggunakan pisau analisis semiotika Peirce.

Berdasarkan beberapa penelitian relevan yang telah disebutkan beserta penjelasannya, maka dapat disimpulkan bahwa belum ada penelitian yang mencoba mengungkap totalitas cinta Rabi'ah AlAdawiyah dalam syairnya dengan menggunakan perspektif Charles Sanders Peirce. Oleh karena itu, penelitian ini merupakan penelitian yang termasuk baru dan dapat dikaitkan dengan penelitian-penelitian terdahulu. Dengan alasan tersebut, maka landasan dilakukannya penelitian ini semakin kuat, sebagaimana prinsip metode ilmiah bahwa penelitian perlu merujuk pada penelitian terdahulu. Solusi ilmiah yang ditemukan dalam suatu penelitian bukanlah akhir dari segala-galanya, sehingga masih bisa dilakukan penelitian terbaru (Dua, 2001:89).

Adapun tujan lebih jelasnya mengenai tujuan dilakukannya penelitian ini adalah untuk menganalisis bagaimana totalitas cinta yang digambarkan melalui bentuk ikon, indeks, dan simbol dalam syair Rabi'ah AlAdawiyah.

Penelitian ini dapat menambah referensi keilmiahan dalam kajian semiotika dan sastra. Penelitian ini juga dapat dijadikan sebagai landasan teoritis bagi yang ingin melakukan penelitian dengan objek dan pendekatan yang relevan

Jurnal Ilmiah Mahasiswa Raushan Fikr Vol. 10, No. 2 Juli-Desember 2021 
Selain kegunaan teoritis, penelitian ini bisa dijadikan sebagai titik dasar untuk meningkatkan praktik penelitian dalam kajian sastra, baik melalui lahirnya inspirasi dan ide penelitian setelah pembacaan penelitian ini, maupun melalui lahirnya kritik-kritik sastra dan penelitian. Bagi institusi pendidikan, penelitian ini dapat menjadi objek pembahasan dalam proses pembelajaran yang dapat dikaji dari sistematika penelitian, substansi, maupun ibrah yang bisa diambil di dalamnya.

Peneliti menganggap bahwa kegunaan penelitian ini bukan hanya berimplikasi pada lingkup kajian ilmiah, tetapi juga kehidupan manusia pada umumnya, karena membahas terkait bagaimana representasi cinta yang total, baik kepada lingkungan, maupun kepada Pencipta alam semesta.

\section{METODE PENELITIAN}

Metode yang digunakan dalam penelitian ini adalah metode deskriptif (almanhaj al-washfi), yakni metode yang memaparkan fakta bahasa dan kebahasaan secara apa adanya. Untuk lebih memperjelas proses penelitian ini, maka penulis menentukan jenis penelitian, data dan sumber data penelitian, metode pengumpulan data, dan teknik analisis data yang dipaparkan sebagai berikut:

Pertama, jenis penelitian. Penelitian ini merupakan penelitian kualitatif, karena mengguanakan paradigma penelitian kualitatif. Penelitian kualitatif merupakan pendekatan yang mendeskripsikan fenomena kebahasaan berupa makna, konsep, definisi, metafora, dan benda (Berg dalam Pribady, 2018).
Selain itu, penelitian kualitatif biasanya bersifat non-numerik, deskriptif, menggunakan penalaran dan menggunakan kata-kata yang bertujuan untuk mendapatkan makna, perasaan, dan menggambarkan situasi (Goundar, 2012). Penjelasan tersebut relevan dengan pembahasan penelitian ini yang akan berfokus ke beberapa konsep semiotika yang nantinya membongkar karya sastra yang menggunakan media bahasa.

Kedua, Data dan Sumber Data. Penelitian ini akan menganalisis totalitas cinta dalam syair Rabi'ah Al-Adawiyah, sehingga data yang akan digunakan adalah beberapa syair dari Rabi'ah Al-Adawiyah. Ketiga, Metode Pengumpulan Data. Metode pengumpulan data adalah langkah yang digunakan dalam penelitian ini untuk memeroleh data. Metode yang digunakan adalah metode simak. Metode simak artinya penyediaan data yang dilakukan dengan menyimak data penggunaan bahasa (e-Prints UMS).

Keempat, Teknik Analisis Data. Teknik analisis data yang digunakan dalam penelitian ini dilakukan dengan menggunakan tiga tahap, yakni penyediaan data, analisis data, dan penyajian hasil analisis (Pribady, 2018).

\section{HASIL DAN PEMBAHASAN}

\section{Semiotika Pierce}

Sebelum mengulas mengenai perspektif semiotika Peirce, baiknya diawali dengan biografi singkatnya. Charles Sanders Peirce lahir pada 10 September 1839, di kota Amerika Cambridge, Massachusetts. Keluarga Peirce terkenal dalam bidang politik, sosial, dan terutama intelektual di Boston,

Jurnal Ilmiah Mahasiswa Raushan Fikr Vol. 10, No. 2 Juli-Desember 2021 
sehingga lingkungan tempat Peirce muda tumbuh dengan lingkungan ilmiah dan filosofis yang cukup kuat. Pada masa remaja ia mengabdikan dirinya untuk memperdalam filsafat dan logika, membaca karya-karya penulis besar. Tahun 1864 dan 1884 Peirce mengajar logika di Universitas Johns Hopkins di Baltimore dan Harvard, tetapi tidak sebagai profesor. Terkait dunia semiotika, kontribusi utamanya adalah mengemukakan bahwa tanda-tanda, kata-kata, tidak hanya apa yang kita gunakan untuk menunjuk objek atau ide, tetapi "apa yang diketahui membuat kita mengetahui sesuatu yang lebih". Berbeda dengan teori klasik Saussure, Peirce berfokus pada aspek umum bahasa, yang didefinisikan sebagai cara manusia mengetahui realitas (Thpanorama, 2020).

Dalam sejarah semiotika modern, Peirce adalah tokoh utama yang dikenal dengan pemikiran filosofisnya, bahkan ada tokoh semiotika yang mencoba mengejar warisan pemikiran Peirce di bidang semiotika umum, yaitu Morris, akan tetapi ia seringkali tidak dapat menjangkau pemikiran filosofi Peirce (Noth W, 1995). Ia membuat konsep semiotika yang berfokus pada sistem triadik dan trikotomi tiga dimensi yang mengklasifikasikan tanda menjadi tiga aspek, representatum, objek, dan interpretant (Halina, 2014). Tiga aspek tersebut kemudian lebih dirincikan lagi oleh Peirce dengan klasifikasi sebagai berikut: Pertama, Tanda Berdasarkan Representatum (Ground). Aspek pertama ini berkaitan dengan sesuatu yang membuat suatu tanda dapat berfungsi. Dalam hal ini Peirce mengklasifikasikannya ke dalam tiga hal yakni, Qualisign (kualitas dari suatu tanda), Sinsign (eksistensi dan aktualitas atas suatu benda atau peristiwa terhadap suatu tanda), dan Legisign (norma yang terkandung dalam suatu tanda).

Kedua, Tanda Berdasarkan Objek. Aspek kedua ini juga dibagi ke dalam tiga hal yakni, ikon (tanda yang menyerupai bentuk objek aslinya), indeks (tanda yang berkaitan dengan hal yang bersifat kausalitas), dan simbol (tanda yang berkaitan kesepakatan sosial). Ketiga, Tanda Berdasarkan Interpretant. Aspek ketiga ini juga dibagi ke dalam tiga hal, yakni Rheme (tanda yang memungkinkan ditafsirkan dalam pemaknaan yang berbedabeda), Dicent sign atau dicisign (tanda yang sesuai dengan fakta dan kenyataanya), dan Argument (tanda yang berisi alasan tentang sesuatu hal).

Berdasarkan tiga aspek tersebut, penulis meneliti tanda berdasarkan trikotomi tanda, sehingga hanya berfokus kepada tiga hal, yaitu ikon, indeks, dan simbol yang nantinya akan ditelusuri lebih jauh dalam syair Rabi'ah Al-Adawiyah. Lebih jauh ketiga aspek tersebut dapat dijelaskan berikut ini: Pertama, Ikon. Ikon merupakan tanda yang memgandung kemiripan dengan acuannya (reference), seperti lukisan pemandangan yang mengikuti bentuk aslinya. Sobur menjelaskan bahwa Ikon adalah benda fisik yang menyerupai apa yang dipresentasikannya. Representasi tersebut ditandai dengan kemiripan (Sobur A. , 2003). Definisi ini dikuatkan dengan definisi dari binus.ac.id., bahwa ikon adalah tanda yang mirip dengan obyek yang diwakilinya, ikon memiliki ciri-ciri yang dimiliki dengan apa yang dimaksudkan. Oleh karena itu, kesimpulan sederhana yang sudah disebutkan di awal sudah tepat bahwa ikon adalah tanda

Jurnal Ilmiah Mahasiswa Raushan Fikr Vol. 10, No. 2 Juli-Desember 2021 
yang memiliki kemiripan dengan acuannya. Contohnya adalah peta Indonesia yang merupakan ikon dari seluruh wilayah di Indonesia.

Kedua, Indeks. Indeks merupakan tanda yang mempunyai keterkaitan fenomenal dan eksistensial antara representamen dan objeknya, seperti asap yang muncul karena adanya proses pembakaran kayu. Hal ini dikuatkan dengan definisi dari binus.ac.id, bahwa indeks merupakan tanda yang memiliki hubungan sebab-akibat dengan apa yang diwakilinya atau disebut juga tanda sebagai bukti. Kemudian pendapat lain mengungkapkan bahwa indeks adalah tanda yang menunjukkan adanya hubungan alamiah antara tanda dan petanda yang bersifat hubungan sebab akibat atau hubungan kausalitas (Sobur A. , 2003).

Ketiga. Simbol. Simbol merupakan tanda yang bersifat konvensional atau sesuai dengan kesepakatan sosial, seperti simbol lalu lintas yang sudah diketahui bersama oleh masyarakat (UDiNus Repository). Website binus.ac.id mengungkapkan definisi yang berkaitan bahwa simbol merupakan tanda berdasarkan konvensi, peraturan, atau perjanjian yang disepakati bersama.

Penjelasan lebih jauh mengenai ikon, indeks, dan simbol dapat juga dipahami melalui kutipan berikut,

This trichotomy classifies signs with respect to the relation between the representamen and object. Peirce referred to this trichotomy as "the most fundamental division of signs. (Handbook of Semiotics, Noth, W., 1995).
Oleh karena itu, dengan menjadikan syair Rabi'ah Al-Adawiyah, penulis akan menelusuri bentuk totalitas cinta melalui tanda yang ada di dalamnya.

\section{Konsep Cinta}

Cinta adalah bagian yang tidak terlepaskan dalam kehidupan manusia, ia selalu ada dalam berbagai dimensi waktu. Siapa saja dapat menyebutkan dan mengekspresikannya ke dalam berbagai hal, sebab pada hakekatnya, cinta adalah hak siapa saja. Keragaman cara dalam mengaktualisasi cinta melahirkan definisi cinta yang juga beragam. Kadang kala cinta diukur dengan prestiese dan harta milik, kadang kala disebut sebagai bentuk pengorbanan secara total demi kebahagiaan orang lain, dan kadang kala cinta dianggap sebagai wujud manifestasi dari keindahan paras. Pertanyaannya, apakah itu yang disebut sebagai cinta?

Gabriel Marcel (Rosyadi, 2015) mengungkapkan bahwa cinta pada dasarnya adalah bentuk tindakan yang berasal dari kemerdekaan seseorang untuk mencintai apa yang ada di luar dirinya. Ia adalah hak dan kewajiban individu, tanpa disertai dengan paksaan. Pendapat lain menyebutkan bahwa cinta adalah jalan pilihan seseorang untuk keluar dari dirinya sendiri, agar tidak terpencil dalam kesendiriannya (Gorard Bibang, hlm. 11).

Selanjutnya dijelaskan bahwa cinta merupakan kebutuhan terdalam pada manusia untuk mengatasi keterpisahannya dengan aspek dari luar dirinya dan meninggalkan kesendirian. Bedasarkan penjelasakn tersebut, maka penulis menyimpulkan secara sederhana 
bahwa cinta adalah keterikatan diri dengan aspek yang ada di luar diri tanpa adanya keterpaksaan, sehingga dengannya ada unsur penyatuan antar satu dengan yang lainnya.

Selain konsep cinta secara umum, sebagaimana konsep cinta Rabi'ah AlAdawiah yang identik dengan konsep mahabbah atau kecintaan kepada Tuhan, maka penulis mengutip pendapat dari Harun Nasution (Wasalmi, 2014), bahwa cinta (mahabbah) ialah memeluk kepatuhan kepada Tuhan dan membenci sikap melawan kepadaNya, menyerahkan seluruh diri kepada yang dikasihi, serta mengosongkan hati dari segalagalanya kecuali dari diri yang dikasihi.

\section{Syair-Syair Rabi'ah Al-Adawiyah}

Rabi'ah al-Adawiyah dengan nama lengkap Rabi'ah binti Isma'il al-Adawiyah alQissiyah merupakan seorang tokoh sufi yang lahir di Basrah antara tahun 713 dan 717 Miladiah, namun disebutkan juga bahwa tahun kelahirannya 714 Miladiah. Rabi'ah kemudian meninggal pada tahun $801 \mathrm{M}$ (Islam, D.A., 1992/1993 M). Ia dikenal sebagai perempuan yang sama dengan perempuan pada umumnya. Sejak kecil ia aktif dengan aktivitas ibadah, menghapal ayat-ayat suci al-Quran dan melakukan ibadah dengan khusyuk. Setelah semakin beranjak dewasa, iya ingin kembali seperti pada masa kecilnya. Rabi'ah lalu bertaubat kepada Tuhan dan pertaubatannya tersebutlah yang membuat ia terbakar di dalam cinta Ilahi.

Salah satu wujud kecintaan Rabi'ah kepada Tuhan digambarkan melalui puisi (syair) yang ia tulis. Rabi'ah memiliki banyak puisi cinta yang berisi tentang kedalaman
cinta-Nya kepada Tuhan. Beberapa di antaranya akan dikaji dalam penelitian ini dengan analisis semiotika trikotomi Peirce.

Beberapa puisi yang akan dianalisis adalah sebagai berikut: Pertama,

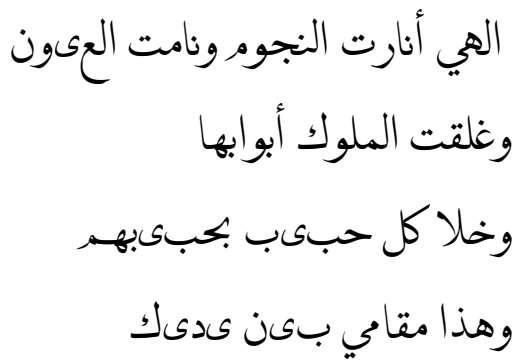

Artinya: "Ya Tuhan bintang di langit telah gemerlapan, mata telah bertiduran, pintupintu istana telah dikunci dan tiap pecinta telah menyendiri dengan yang dicintainya dan inilah aku berada di hadirat-Mu." (Wasalmi, 2014).

Kedua,

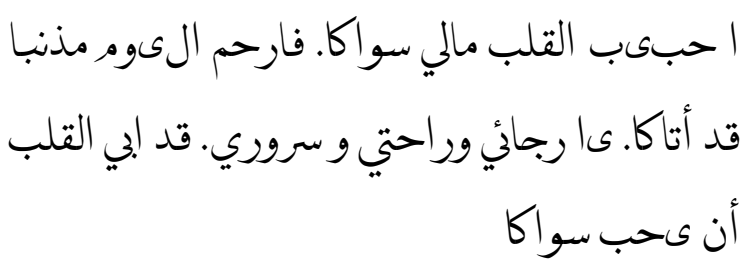

Artinya: "Buah hatiku, hanya Engkaulah yang kukasihi. Beri ampunlah pembuat dosa yang datang ke hadirat-Mu. Engkaulah harapanku, kebahagianku dan kesenanganku. Hatiku telah enggan mencintai selain dari Engkau." (Wasalmi, 2014).

Ketiga,

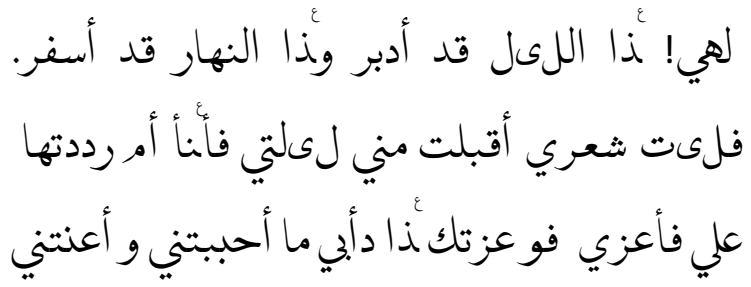




$$
\text { وعزتك قبل لو طردتني عن بابك ما برحت عنهم لما وقع }
$$

Artinya: "Tuhanku, malam telah berlalu dan siang segera menampakkan diri. Aku gelisah, apakah amalanku Engkau terima hingga aku merasa bahagia, ataukah Engkau tolak hingga aku merasa sedih. Demi ke Mahakuasaan-Mu, inilah yang akan aku lakukan selama aku Engkau beri hayat. Sekiranya Engkau usir aku dari depan pintu-Mu, aku tidak akan pergi, karena cinta pada-Mu telah memenuhi hatiku” (Wasalmi, 2014).

Keempat,

$$
\text { ما غبدت الله خوفا من ناره... }
$$

$$
\begin{aligned}
& \text { و لا طمعا لجنته فأكون كألجير السوء إن خاف } \\
& \text { عمل... بل عبدته حبا له و شثوقا إليه }
\end{aligned}
$$

Artinya: "Tidaklah aku menghambakan diri pada Tuhan karena takut akan nerakaNya... Juga tidak tamak pada surgaNya yang menjadikanku bagaikan mendapat ganjaran buruk jika melakukan sesuatu secara diamdiam. Namun, aku menghambakan diri karena cinta dan merindukan-Nya." (Bustam, 2014).

Kelima,

أحبك حبين: حب الهوي .و حباّ لأنك أهل لذاكا.

فأما الذي هو حب الهوي .فثغلي بذكرك عمن سواكا .وأما الذي أنت أهل له. فكثفك للحجب أنوي حتي أراكا .فلا الحمد في ذا، و لا ذالك. و لكن لك

$$
\text { الحمد في ذاو ذاكا }
$$

Artinya: "Aku mencintaiMu dengan dua cinta: cinta karena perasaan cinta. Dan cinta karena Engkaulah cinta (sebenarnya). Adapun cinta dengan perasaan cinta itu. maka aku sibuk mengingatMu dengan hal selain (dzat)-Mu. Sedangkan cinta karena Engkaulah cinta. Maka Kau singkap tabir-tabir hingga aku melihat-Mu Tiadalah pujian untuk cinta yang ini maupun itu untukku. Tetapi, bagi-Mu-lah pujian (untuk) kedua cinta itu" (Bustam, 2014).

Keenam,

$$
\begin{aligned}
& \text { إلهي! إن كنت عبدتك خوف النار فأحرفني با النار، } \\
& \text { أو طمعا في الجنة فحرهما علي... و إن كنب لا أبدتك } \\
& \text { إلآ من أجلك، فلا تحر مني من مثاهدة وجهك }
\end{aligned}
$$

Artinya: "Tuhanku, jika aku menghamba pada-Mu (karena) takut akan neraka, maka pangganglah aku di dalamnya. Atau (karena) aku sangat mengharapkan surga, maka haramkanlah surga bagi diriku. Namun, jika aku menghamba pada-Mu sematamata karena Engkau, Maka jangan haramkan aku untuk melihat rupaMu (di Akhirat)." (Bustam, 2014).

Ketujuh,

كأسي و خمري و النديم ثلاثنة و أنا المكثوقة في

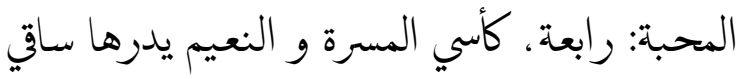

المداه علي المدي متتابعة ، فإذا نظرت فلا أرى إلا

له وإذا حضرت فلا أرى إلا معه ، يا عاذلي إنى أحب جماله تاالله ما أذنى لعذلك سامعه، كم بت من خرق و فرط تعالقى أخرى عيونا من عيونى الدامعة ، لا عبرتى ترقا ولا و صلى له يبقى ولا عينى القريحة هاجعة 
Artinya: "Cawanku, anggurku, dan buih adalah tiga (unsur) (sedangkan) aku si perindu cinta: (unsur ke-) empat. Cawan yang dikelilingi kemudahan dan kesenangan. Selalu menjadi pelepas dahaga. Jika aku memandang (ke arah manapun), aku tidak melihat selain Dia. Dan jika aku hadir (di suatu tempat), maka aku tak terlihat kecuali bersamaNya. Duhai keabadian, sungguh aku mencintai keindahanNya. Demi Tuhan, telingaku belum mendengar tentang ketidaksempurnaanMu. Berapa banyak sudah pelanggaran dan kesalahanku yang terjadi. Air mata terus bercucuran di mataku. Tidaklah pelajaranku meningkat dan tidak pula pencapaianku padanya. Tersisa, tidak pula bagian mataku terjaga." (Bustam, 2014).

\section{Analisis Totalitas Cinta dalam Bentuk Ikon}

Berdasarkan tujuh data yang dianalisis, ditemukan dua bentuk ikon dalam syair Rabi'ah Al-Adawiyah, antara lain: Pertama, Bintang sebagai Tanda Malam.

الهي أنارت النجومِونامت العىون (syair pertama) Yang berarti, "Ya Tuhan bintang di langit telah gemerlapan, mata telah bertiduran”

Kedua, Istana sebagai Tanda Tempat. وغلقت

(dalam syair pertama) yang

berarti "pintu-pintu istana telah dikunci"

Kedua kata tersebut dikategorikan sebagai bentuk ikon, karena memiliki keterkaitan erat atau kesamaan dengan apa yang dimaksudnya, bahwa kemunculan bintang memang menjadi tanda malam hari dan istana merupakan tempat yang bentuknya seperti yang telah diketahui sebelumnya, berupa bangunan dan di dalamnya dihuni oleh beberapa orang.

Berdasarkan dua ikon yang ditemukan tersebut, kedalaman cinta diekspresikann dengan pemilihan diksi "bintang" di malam hari dan "istana" yang telah tertutup. Dua ikon tersebut menunjukkan suasana hening di malam hari. Keheningan tersebut seolah mewakili suasana batin yang fokus mengadukan rasa dan cinta kepada Tuhan.

\section{Totalitas Cinta dalam Bentuk Indeks}

Berdasarkan tujuh data yang dianalisis, ditemukan beberapa bentuk indeks dalam syair Rabi'ah Al-Adawiyah, antara lain: Pertama, Indeks 1.

(syair kedua) Yang berarti: "Hatiku telah enggan mencintai selain dari Engkau." Kutipan syair tersebut menunjukkan bentuk indeks, karena ada hukum kausalitas, bahwa Rabi'ah tidak mau lagi mencintai selain kepada Tuhan. Hal tersebut disebabkan oleh cinta Rabi'ah kepada-Nya yang seolah telah penuh dan tidak bisa digantikan lagi. Pada contoh ini, penulis menyimpulkan bukti totalitas cinta dari Rabi’ah.

Kedua, Indeks 2.

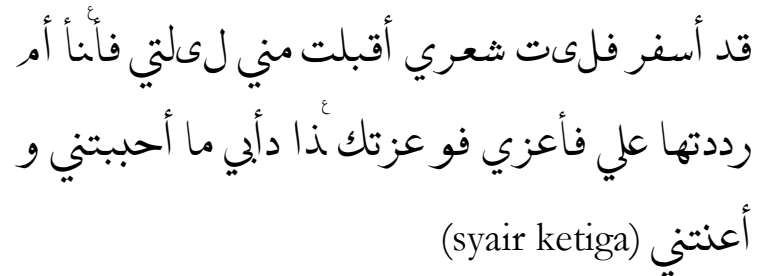

Yang berarti: "Aku gelisah, apakah amalanku Engkau terima hingga aku merasa bahagia, ataukah Engkau tolak hingga aku 
merasa sedih." Kutipan syair tersebut menunjukkan bentuk indeks, karena ada hukum kausalitas, bahwa Rabi'ah merasakan kegelisahan karena khawatir proses pengampunannya tidak diterima olehNya. Selanjutnya ia akan sedih jika itu benar-benar ditolak.

Ketiga, Indeks 3.

$$
\begin{aligned}
& \text { لو طردتني عن بابك ما برحت عنهم لما وقع في } \\
& \text { قلبي من محبتك ( syair ketiga) }
\end{aligned}
$$

Yang berarti: "Sekiranya Engkau usir aku dari depan pintu-Mu, aku tidak akan pergi, karena cinta pada-Mu telah memenuhi hatiku." Kutipan syair tersebut menunjukkan bentuk indeks, karena ada hukum kausalitas, bahwa Rabi'ah sama sekali tidak akan pergi dariNya, kalaupun ia akan diusir. Hal tersebut disebabkan karena cintanya kepada Tuhan telah menemani hatinya. Hukum kausalitas tersebut menunjukkan betapa dalamnya cinta Rabi'ah, sehingga ia merasa bahwa cinta itu telah menyatu dengan dirinya.

Keempat, Indeks 4.

ما غبدت الله خوفا من ناره (syair keempat) Yang berarti: "Tidaklah aku menghambakan diri karena cinta dan merindukan-Nya." Kutipan syair tersebut menunjukkan bentuk indeks, karena ada hukum kausalitas, bahwa wujud penghambaan Rabi'ah kepada Tuhan bukanlah semata-mata karena takut akan neraka, tetapi disebabkan oleh totalitas cinta yang ia miliki, sehingga perasaan yang dimiliki tidaklah mengharapkan imbalan apa pun. Hal tersebut menunjukkan cinta yang seutuhnya.
Kelima, Indeks 5.

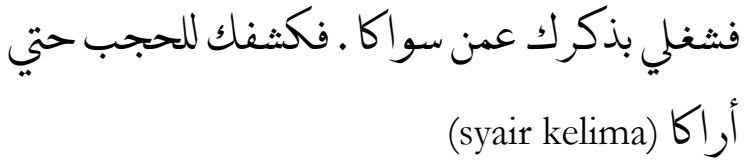

Yang artinya: "Sedangkan cinta karena Engkaulah cinta, kau singkap tabirtabir, hingga aku melihat-Mu" Kutipan syair tersebut menunjukkan bentuk indeks, karena ada hukum kausalitas, bahwa Allah membukakan tabir-tabir pemisah antara dirinya denganNya, sehingga ia seolah mampu melihatNya. Hal tersebut disebabkan oleh kedalaman cinta yang dirasakan oleh Rabi'ah. Potongan syair tersebut membuktikan totalitas cinta, karena cinta yang total adalah ketika ada rasa penyatuan dan tidak ada sekat antara diri dengan yang dicintai.

Keenam, Indeks 6

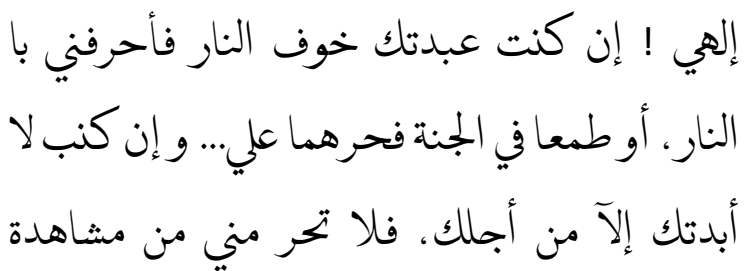

وجهك (syair keenam)

Artinya: "Tuhanku, jika aku menghamba pada-Mu (karena) takut akan neraka, maka pangganglah aku di dalamnya. Atau (karena) aku sangat mengharapkan surga, maka haramkanlah surga bagi diriku.. Namun, jika aku menghamba pada-Mu sematamata karena Engkau, Maka jangan haramkan aku untuk melihat rupaMu (di Akhirat)." Kutipan syair tersebut menunjukkan bentuk indeks, karena ada hukum kausalitas, bahwa Rabi'ah rela untuk dipanggang dan rela diharamkan terhadapnya surga jika ia mencitaiNya hanya karena mengharapkan imbalan. Hal tersebut lagi-lagi disebabkan oleh kedalaman cinta 
yang dirasakan oleh Rabi'ah, cinta yang total, tanpa mengharapkan imbalan apapun.

Ketujuh, Indeks 7

$$
\text { لا عبرتى ترقا ولا و صلى له ، يبقى (syair ketujuh) }
$$

Artinya: "Berapa banyak sudah pelanggaran dan kesalahanku yang terjadi. Air mata terus bercucuran di mataku." Kutipan syair tersebut menunjukkan bentuk indeks, karena ada hukum kausalitas, bahwa Rabi'ah menangis, karena merasakan atas segala pelanggaran dan kesalahan yang ia lakukan. Penyesalan tersebut merupakan wujud dari cinta Rabi'ah kepadaNya.

Kedelapan, Indeks 8

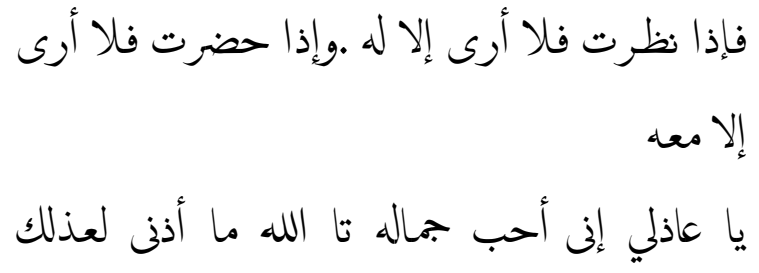

سامعه (syair ketujuh)

Artinya: "Jika aku memandang (ke arah manapun), aku tidak melihat selain Dia. Dan jika aku hadir (di suatu tempat), maka aku tak terlihat kecuali bersamaNya. Duhai keabadian, sungguh aku mencintai keindahan-Nya." Kutipan syair tersebut menunjukkan bentuk indeks, segala yang diungkapkan oleh Rabi'ah dalam syair tersebut semata-mata karena bentuk totalitas cintanya kepada Tuhan dan tidak akan pernah teralihkan. Itulah bentuk totalitas cinta.

Berdasarkan delapan bentuk indeks yang telah dianalisis tersebut, penulis menyimpulkan bahwa Rabi'ah benar-benar menunjukkan totalitas cintanya melalui syairsyairnya. Hal tersebut diwakili oleh beberapa tanda yang telah disebutkan. Totalitas cinta tersebut berupa pengorbanan, kerelaan, rasa kemelekatan, ketakutan untuk berbuat salah, ketidakpedulian terhadap imbalan, dan ketidakinginan untuk beralih kepada yang lain.

\section{Totalitas Cinta dalam Bentuk Simbol}

Berdasarkan tujuh data yang dianalisis, ditemukan tiga bentuk simbol dalam syair Rabi'ah Al-Adawiyah, antara lain: Pertama, Simbol 1.

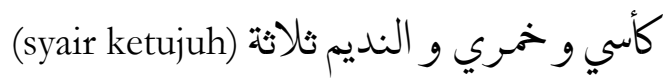
Artinya: "Cawanku, anggurku, dan buih adalah tiga (unsur)." Dua kata dalam potongan syair tersebut merupakan bentuk simbol. Cawan dan anggur adalah dua kata yang sudah menjadi konvensi sosial, bahwa keduanya menandakan "kemabukan". Penggunaan kata tersebut mewakili bentuk totalitas cinta Rabi'ah kepada Tuhan yang seolah menggambarkan bahwa, cinta yang ia rasakan telah merasuk begitu dalam, hingga pikirannya hanya tertuju pada satu. Simbol cinta tersebut mengartikan bahwa kadang kala cinta membuat lupa akan diri sendiri.

Kedua, Simbol 2.

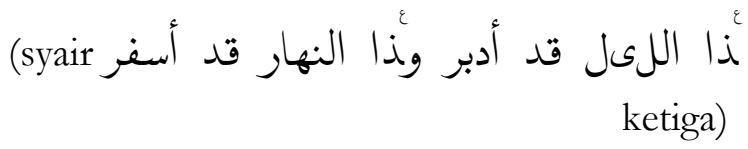

Artinya: "Malam telah berlalu dan siang segera menampakkan diri." Dua kata dalam potongan syair tersebut merupakan bentuk simbol dari pergantian malam. Tanpa dijelaskan kembali, siapa saja dapat memahami bahwa malam dan siang merupakan simbol dari pergantian hari. Simbol tersebut menjadi bukti kedalaman cinta Rabi'ah karena menjadikan waktu yang ia jalani semata untuk merenungi, mengadu, dan menunjukkan cintanya kepada Tuhan. 
Ketiga, Simbol 3.

ما غبدت الله خوفا من ناره (syair keempat) Artinya: "Tidaklah aku menghambakan diri pada Tuhan karena takut akan nerakaNya" Kata abadtu dalam potongan syair tersebut merupakan bentuk simbol dari aktivitas ibadah. Tanpa dijelaskan kembali, siapa saja dapat memahami bahwa proses penghambaan diri kepada Allah adalah bentuk ibadah. Ibadah yang maksudkkan oleh Rabi'ah tersebut adalah bentuk usahanya untuk semakin mendekat kepadaNya sebagai simbol manifestasi cinta kepada sang Ilahi. Hal ini ditegaskan dengan pernyataan lengkapnya, bahwa ibadahnya bukan dilakukan karena rasa takut neraka.

\section{SIMPULAN}

Berdasarkan hasil penelitian dengan menggunakan kajian semiotika berdasarkan perspektif Charles Sanders Peirce terhadap syair-syair Rabi'ah Al Adawiyah, maka disimpulkan bahwa kedalaman cinta Rabi'ah al-Adawiyah tergambarkan dari dua ikon; bintang dan istana, delapan indeks; berupa pengorbanan, kerelaan, rasa kemelekatan, ketakutan untuk berbuat salah, ketidakpedulian terhadap imbalan, dan ketidakinginan untuk beralih kepada yang lain, dan tiga simbol; cawan dan anggur, malam dan siang, dan aku menghamba.

\section{DAFTAR PUSTAKA}

Ambarini AS, M. d. (n.d.). Semiotika Teori dan Aplikasinya pada Karya Sastra. Semarang: IKIP PGRI Semarang Press.

Asriningsari, A. (2016). Jendela Kritik Sastra: Menjadi Kritikus Akademika Melalui Jendela
Kritik Sastra Indonesia. Semarang: Universitas PGRI Semarang.

Baso, Y. S. (2016). Model pembelajaran Bahasa Arab Online berbasis Learning Management System. Makassar: Program Studi Sastra Asia Barat Universitas Hasanuddin.

Bustam, B. M. (2014). Analisis Semiotika Terhadap Puisi Rabi'atul Adawiyah Dan Kalimat Suci Mother Teresa. Analisa, 227238.

Fadlil Munawwar Manshur, M. (2007). Sejarah Kesusastraan Arab dan Klasik. Makalah Fakultas Ilmu Budaya UGM, 4.

Dua, A. S. (2001). Ilmu Pengetabuan : Suatu Tinjauan Filosofis. Yogyakarta: Penerbit Kanisius.

Fachrudin, A. A. (2017). Pengantar Sejarah dan Mazhab Linguistik Arab. Sukodomo Sidoarjo: Lisan Arabi.

Fadly, A. (2020, Januari 18). Retrieved from Binus University:https://binus.ac.id/malang/2020/01/i kon-indeks-simbol/

Grice, H. (1975). Logic and Conversation. London: University College London.

Ibeng, P. (2020, Desember 13). Retrieved Januari 22, 2021, from Pendidikan.co.id: https://pendidikan.co.id/pengertian-kristiksastra-fungsi-ciri-manfaat-dan-pendekatan/

Indonesia), K. (. (n.d.). Islam, D. A. (1992/1993 M). Ensiklopedi Islam. Jakarta: Anda Utama.

Jafar Lantowa, N. M. (2017). Semiotika: Teori, Metode, dan Penerapannya dalam Penelitian Sastra. Yogyakarta: Penerbit Deepublish.

Leech, G. (1983). Linguistic Meaning (Vol 1). London: Routledge \& Kegan Paul. 
Levinson, S. C. (1983). Pragmatics. Cambridge: Cambridge University Press.

Nasution, H. (1983). Falsafat dan Mistisisme Dalam Islam. Jakarta: Bulan Bintang.

Noth, W. (1995). Handbook of Semiotics. United States of Amerika: Library of Congress Catalogingin-Publication Data.

Nurhayati, T. (2019). Representasi Cinta Pada Allah Dalam Syair Rabi'ah Al-Adawiyah Dan Syair Husain Manshur Al-Hallaj (Kajian Sastra Bandingan). Tafhim al-Tlmi: Jurnal Pendidikan dan Pemikiran Islam, 1-11.

Rosyadi, K. (2015). Cinta dan Keterasingan. Yogyakarta: LKiS Pelangi Aksara.

Shihab, N. (Director). (2020). Catatan Najwax Agnez.Mo | Catatan Najwa [Motion Picture].

Sobur, A. (2002). Bercengkerama dengan Semiotika. Mediator, Vol. 3, No. 1, 31-50.

Sobur, A. (2003). Semiotika Komunikasi. Bandung: Remaja Rosdakarya.

Thpanorama. (n.d.). Charles Sanders Peirce Biografi dan Kontribusi. Retrieved Oktober 21, 2020, from Thpanorama: https://id.thpanorama.com/articles/filosofa / charles-sanders-peirce-biografa-yaportaciones.html

Wasalmi. (2014). Mahabbah dalam Tasawuf Rabi'ah Al Adawiyah. Sulesana, 81-87.

Wijaya, I. D. (1996). Dasar-Dasar Pragmatik. Yogyakarta: Penerbit Andi.

Yule, G. (1996). Pragmatics. Oxford: Oxford University Press. 